\section{WHATT}

\section{2,4}

364

\title{
Competitive destination analysis in Southern European countries
}

\author{
Paulo Águas, Célia Veiga and Helena Reis
} Escola Superior de Gestão, Hotelaria e Turismo, Universidade do Algarve, Faro, Portugal

\begin{abstract}
Purpose - The purpose of this paper is to analyse the competitiveness of the European Union Member States of Southern Europe (France, Greece, Italy, Portugal and Spain) as tourist destinations for European Union Member States of Central and Northern Europe (Austria, Belgium, Denmark, Finland, Germany, The Netherlands, Ireland, Sweden and the UK).

Design/methodology/approach - Application of the market share analysis tool, initially developed by Faulkner, using secondary data from Eurostat - statistical office of the European communities.

Findings - The results obtained show that France, Greece, Italy, Portugal and Spain present distinct levels of competitiveness for the various generating countries, with changes having occurred in the period between 1999 and 2007.

Originality/value - The paper offers refreshment of Faulkner's tool and an insight into tourist flows in Europe as a tool for tourism and hospitality managers.
\end{abstract}

Keywords Tourism, Situation analysis, Market share, Competitive strategy, Market research, European Union

Paper type Research paper

\section{Introduction}

Competitiveness is a widespread concern in contemporary society. Issues such as an increasing globalization and the shift from commodity-based economies towards economies driven by knowledge, innovation and commercialization (Ruhanen, 2007, p. 134) are perceived as strong determinants for the rise of competition.

The competitiveness of an industry has become a critical determinant for a well-founded performance in world markets (Crouch and Ritchie, 1999). However, the concept of competitiveness is no longer restricted to economic activities. It has filtered out from organisational domains to reach other subjects, such as countries and individuals. To be competitive has become a central objective, the condition to be achieved by all.

In the tourism field, where competition is recognized as increasingly intense (Lee et al., 2006; Buhalis, 2000) authors such as Crouch and Ritchie (1999) support the idea that prosperity depends intimately upon tourism destination competitiveness. Following this thought Gomezelj and Mihalic (2008, p. 294) argue that the "degree to which a country can benefit from its tourism sector depends largely on this sector's competitive position in the international tourism market".

Destination marketing success depends deeply on the selection of competitive

Worldwide Hospitality and Tourism Themes

Vol. 2 No. 4, 2010

pp. $364-375$

(c) Emerald Group Publishing Limited $1755-4217$

DOI $10.1108 / 17554211011074029$ markets portfolio. As argued by Smeral and Witt (2002, p. 287) "the overall competitive position of a destination in international tourist should form a sound basis for optimizing the allocation of financial resources and analysing general marketing and supply strategies". The market share analysis (MSA) tool has proven to be an effective performance measure to evaluate the relative competitive position and, therefore, 
a fundamental tool assisting the National Tourism Organization in the construction of successful marketing strategies.

By applying the MSA tool, a study is made concerning the competitiveness of European Union Member States of Southern Europe (France, Greece, Italy, Portugal and Spain) as tourist destinations, in relation to European Union Member States of Central and Northern Europe (Austria, Belgium, Denmark, Finland, Germany, The Netherlands, Ireland, Sweden and the UK) as tourist generating markets.

\section{Theoretical background}

There is no exact, universal definition of the term competitiveness (Feurer and Chaharbaghi, 1994). In a generic approach, the concept implies a degree of superiority, expressed qualitative or quantitatively, of one unit (firm, territory, etc) over the real and potential competitors set (Cracolici and Njikamp, 2008; Crouch and Ritchie, 1999).

However, in organisational terms, competitiveness can have different meanings depending on the situation. This ambiguity, as put forward by Porter (1990), is the result of a wide variety of perspectives on competitiveness and makes it difficult to give an operational or conclusive definition. More specifically, other authors agree that the complexity of the concept derives from its relative nature and multidimensional character (Dwyer and Kim, 2003; Ritchie and Crouch, 1993). In spite of this complexity, one may conclude that, in all cases, the essence of competitiveness resides in the central competences of each organisation.

In the tourism industry, destination competitiveness is becoming an area of growing interest amongst tourism researchers (Cracolici and Njikamp, 2008; Enright and Newton, 2004; Dwyer and Kim, 2003; Buhalis, 2000; Crouch and Ritchie, 1999).

Porter (1990) introduced the first studies about competitiveness of countries and the principal economic sectors in the 1980s. Ritchie and Crouch (1993) considered that the models purposed by Porter together with the World Economic Forum constitute sound bases for the development of an approach to competitiveness in tourism. The Porter Five Diamond's Model is the basis for their comprehensive model on tourism competitiveness. However, these authors further contest the case for the development of a model specifically for tourism, based on the differences between the tourism product and more traditional goods and services. They proceed to identify possible variables for the functions defined in the model, but do not take it to the operational stage due to its underlying complexity.

More recently, several studies tried to put into practice the model proposed by Ritchie and Crouch, with a particular focus on the environmental perspective (Gomezelj and Mihalic, 2008; Enright and Newton, 2004; Mihalic, 2000).

Previous contribution by Gearing et al. (1974) proposes a much simpler model to determine the competitiveness of a tourist destination, with the following four stages:

(1) selection of the criteria for the evaluation of competitiveness;

(2) determination of the relative importance of each criterion;

(3) attribution of points to the criteria; and

(4) calculation of the value of competitiveness (this consists of adding up the points attributed to the criteria).

Several empirical studies continue to use Gearing's approach. The supply perspective (Henshall and Roberts, 1985) or the demand perspective (Kozak and Rimmington, 1999)
Competitive destination analysis

365 
WHATT

2,4

366 can be the bases for the evaluation. Bibliographical research and/or destination experts' opinion are the main sources for the list of selected criteria.

Notwithstanding the emergence of other instruments, such as portfolio analysis or the model of industry attractiveness, potential sales continue to be a key indicator in the evaluation of performance. In tourism, tourist arrivals, overnight stays and revenue constitute, among others, sales proxies, but due to differences in the production of statistics, overnight stays appear to be the most reliable indicator (Mazanec, 1986b). Eusebio et al. (2006) argue that market share is particularly pre-eminent "among measures of comparison with the competition" and is one of the most used measures in the academic field, as well as in business practice.

The MSA is an important instrument in assessing the competitive position of tourism destinations. Faulkner (1997, p. 23) maintained that the fundamental objective of national tourism administrations in their efforts to promote their destinations abroad is to "increase the country's market share beyond that which might otherwise have been achieved".

The importance of the information provided by MSA is also pointed out by Durbarry and Sinclair (2003) who defend that changes in a destination's shares of its major markets can bring about considerable economic repercussions. Departing from these concerns, Smeral and Witt (2002) developed an evaluation scheme based on indices of market share.

Several empirical studies on the issue of competitiveness of destinations have attempted, simultaneously, to evaluate the attractiveness of generating markets (Cracolici and Njikamp, 2008; Faulkner, 1997; Bonn and Brand, 1995; Mazanec, 1995, 1986a, b; McKercher, 1995; Wynegar, 1994; Loker and Perdue, 1992; Rita, 1992; Calantone and Mazanec, 1991; Henshall and Roberts, 1985).

\section{Methodology for evaluating tourism destination's performance}

The proposed tool of analysis allows us to evaluate the performance of the destinations and thus to draw conclusions about the general level of competitiveness. It does not permit, however, the identification of specific causes.

The starting point is the MSA developed by Faulkner (1997). The indicators share deviation (SD) and share variation (SV) are the main variables of the MSA. SD is a temporally static indicator which, from the point of view of destination analysis, compares the market share of destination $\mathrm{A}$ in the generating country $\mathrm{i}$ with the (average) market share of destination $\mathrm{A}$ in the whole set of generating countries under study, at a specific moment in time. For its quantification, we suggest the following expression:

$$
\mathrm{SD}_{\mathrm{i}}=[(M S A i / \overline{M S} A i)-1] \times 100
$$

where:

$\mathrm{SD}_{\mathrm{i}}$ - Share deviation in country of origin $\mathrm{i}$, at the moment in time $\mathrm{t}$.

$M S A i$ - Market share of destination A in country of origin i, at the moment in time $t$.

$\overline{M S} A i$ - Market share (average) of destination $\mathrm{A}$ in the generating countries under study, at the moment in time t. 
$\mathrm{SV}$ is a temporally dynamic indicator which, from the point of view of destination analysis, compares the growth rate in tourist flows from the country of origin i to destination A with the growth rate of tourist flows from the country of origin $i$ to the set of competing destinations under study, for a determined period of analysis. For its quantification, we suggest the following expression:

$$
\mathrm{SV}_{\mathrm{i}}=\text { TFiA }- \text { TFiN }
$$

SVi - Share variation in country of origin $i$, at the moment in time $t$.

TFiA - Variation of tourist flows from country of origin i to destination A, between the moments in time 0 and $t$.

TFiN - Variation from country of origin i to the destinations under analysis, between the moments in time 0 and $t$.

Under normal circumstances, the entry of a (new) generating country, for which the (past) tourist flows were almost nil, will be associated with a negative SD and a positive SV (fourth quadrant, e.g. Position A - see Figure 1).

From Position A, there are two possible scenarios. In case of success, where the SV is persistently positive, the destination will end up showing a market share in the new country of origin, which is above its average share (positive SD). Therefore, the generating country will move to the first quadrant (e.g. Position B). In case of failure, where there is a rapid shift to a negative SV, the generating country will move to the third quadrant (e.g. Position D).

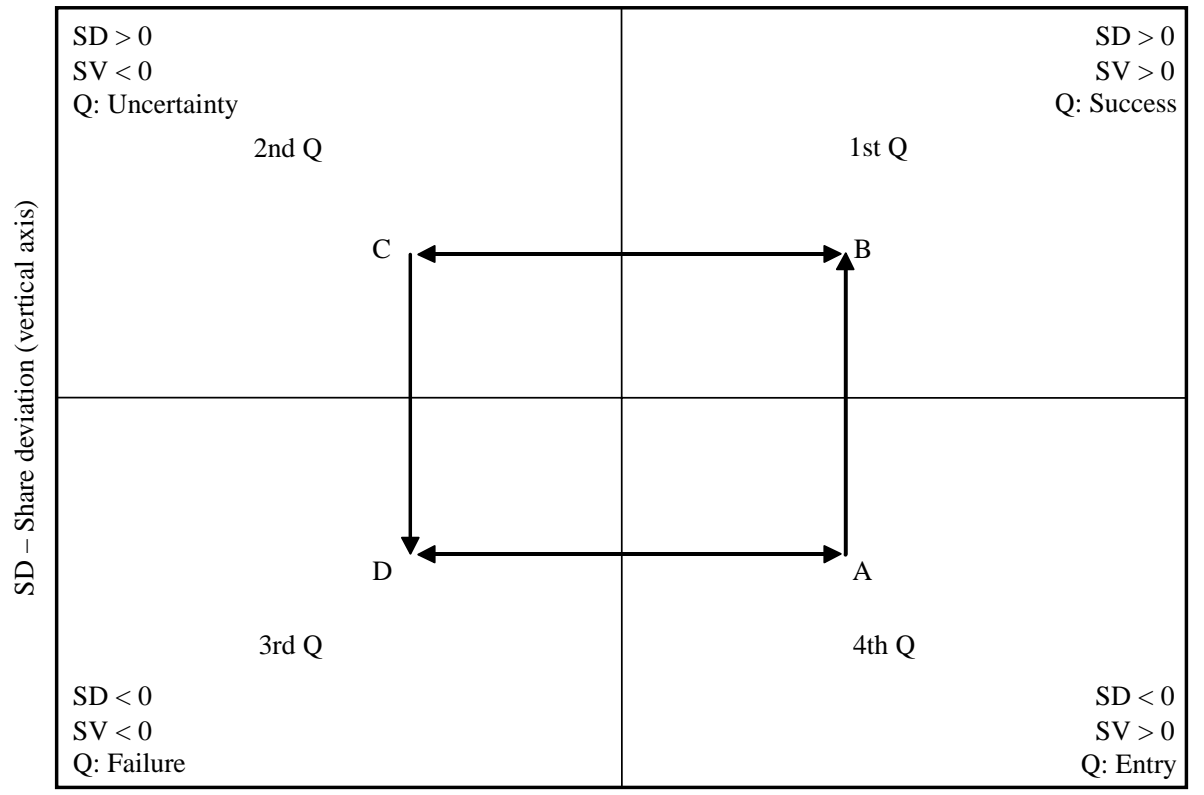

SV - Share variation (horizontal axis)
Competitive destination analysis

367 
WHATT

2,4

368
After a situation of success has been reached (positive SD and positive SV, e.g. Position B), two scenarios are available. If success persists, the generating country will remain in the first quadrant. However, if there is a move towards negative SV, the generating country will change over to a situation of uncertainty (second quadrant, e.g. Position C).

If it is not possible to avoid a situation of failure (negative SD and negative SV, e.g. Position D), once again there are two possible scenarios. If there is no improvement and the situation of negative SV continues, the generating country will remain in the third quadrant. Alternatively, there may be a re-launching of the destination in the generating country, which will permit the return of gains in market share and a new situation of entry (fourth quadrant, e.g. Position A).

It is also relevant to keep in mind the importance of the generating country. Its representation should occur within a circle, centred on the value of the coordinate (SV,SD). Once the values of SV and SD for all the destinations are obtained, it is possible to conduct an analysis by generating country. This is indeed, the most appropriate approach to study the position of a particular destination in relation to its competitors. The only change occurs in the area of the circle, which becomes proportionate to the market share of the destination in that specific generating country.

For the present study, the objectives are:

- To characterise the spread of overnight stays in the hotel establishments of France, Greece, Italy, Portugal and Spain, originating from European Union Member States of Central and Northern Europe.

- To study the recent evolution, between 1999 and 2007, of the competitive position of France, Greece, Italy, Portugal and Spain, in relation to European Union Member States of Central and Northern Europe.

The following hypotheses were tested:

H1. The relative tourist competitiveness of France, Greece, Italy, Portugal and Spain has not been altered.

H2. France, Greece, Italy, Portugal and Spain show distinct levels of competitiveness in the generating countries under analysis.

Requirements to develop a MSA:

- a group of generating regions - Austria, Belgium, Denmark, Finland, Germany, The Netherlands, Ireland, Sweden and the UK;

- a group of destination regions - France, Greece, Italy, Portugal and Spain;

- a performance variable - nights spent in hotel and similar establishments, available at Eurostat database; and

- a minimum of two periods - will be 2000 (1999-2001 annual average), 2003 (2002-2004 annual average) and 2006 (2005-2007 annual average).

Owing to missing data, it was not possible to extend neither the period of analysis nor the regions to other countries, namely the most recent European Union Member States. To minimize the effect of annual unexpected figures, each observation is an average of three years. Table I presents the data used to develop the MSA. 


\begin{tabular}{|c|c|c|c|c|c|c|c|}
\hline Country of residence & France & Greece & Italy & Portugal & Spain & Total & \multirow{3}{*}{$\begin{array}{r}\text { destination } \\
\text { analysis }\end{array}$} \\
\hline \multicolumn{7}{|l|}{2006} & \\
\hline Austria & 388,416 & $1,552,647$ & $4,778,670$ & 297,950 & $1,187,332$ & $7,017,683$ & \\
\hline Belgium & $5,136,287$ & $1,504,862$ & $2,803,555$ & 556,000 & $5,052,174$ & $10,000,705$ & \multirow{4}{*}{369} \\
\hline Denmark & 522,887 & 841,566 & $1,129,513$ & 478,010 & $1,494,859$ & $2,971,976$ & \\
\hline Finland & 189,445 & 696,593 & 655,819 & 378,303 & 790,840 & $1,920,160$ & \\
\hline Germany & $6,869,489$ & $9,128,478$ & $27,644,620$ & $3,870,797$ & $43,329,069$ & $47,513,385$ & \\
\hline Ireland & 639,493 & 247,538 & $1,345,005$ & 971,395 & $2,402,935$ & $3,203,432$ & \\
\hline The Netherlands & $3,462,923$ & $2,415,965$ & $2,824,805$ & $1,766,845$ & $5,559,491$ & $10,470,538$ & \\
\hline Sweden & 547,640 & $1,334,428$ & $1,399,880$ & 554,173 & $2,286,556$ & $3,836,122$ & \\
\hline UK & $15,516,992$ & $7,485,542$ & $10,644,953$ & $7,446,963$ & $43,653,292$ & $41,094,451$ & \\
\hline Sub-total & $33,273,574$ & $25,207,619$ & $53,226,821$ & $16,320,436$ & $105,756,548$ & $128,028,450$ & \\
\hline Total & $71,842,234$ & $43,314,608$ & $107,657,904$ & $25,285,958$ & $148,416,073$ & $396,516,777$ & \\
\hline \multicolumn{8}{|c|}{ 然 } \\
\hline Austria & 423,544 & $1,654,168$ & $4,740,810$ & 243,046 & 948,887 & $7,061,568$ & \\
\hline Belgium & $4,966,477$ & $1,471,098$ & $2,591,543$ & 516,474 & $5,421,324$ & $9,545,593$ & \\
\hline Denmark & 573,039 & 791,779 & 769,034 & 325,741 & $1,003,351$ & $2,459,593$ & \\
\hline Finland & 159,788 & 625,668 & 453,485 & 366,547 & 633,091 & $1,605,489$ & \\
\hline Germany & $7,642,557$ & $9,965,793$ & $28,380,162$ & $3,925,303$ & $38,115,087$ & $49,913,816$ & \\
\hline Ireland & 464,942 & 231,744 & 822,595 & $1,012,311$ & $1,762,845$ & $2,531,592$ & \\
\hline The Netherlands & 3,897,397 & $1,863,126$ & $2,413,913$ & $1,662,724$ & $5,335,585$ & $9,837,160$ & \\
\hline Sweden & 575,907 & $1,385,601$ & $1,159,262$ & 628,078 & $2,118,262$ & $3,748,848$ & \\
\hline UK & $17,079,355$ & $7,928,016$ & $9,218,229$ & $7,290,615$ & $43,477,933$ & $41,516,215$ & \\
\hline Sub-total & $35,783,007$ & $25,916,993$ & $50,549,034$ & $15,970,839$ & $98,816,364$ & $128,219,873$ & \\
\hline Total & $72,438,714$ & $39,472,987$ & $96,315,549$ & $23,259,795$ & $135,785,164$ & $367,272,209$ & \\
\hline \multicolumn{8}{|c|}{ whe } \\
\hline Austria & 447,411 & $2,087,955$ & $5,090,935$ & 289,191 & $1,066,089$ & $7,915,492$ & \\
\hline Belgium & $5,017,811$ & $1,513,577$ & 2,528,951 & 548,736 & $6,256,327$ & $9,609,076$ & \\
\hline Denmark & 670,332 & $1,021,762$ & 842,991 & 439,793 & $1,077,986$ & $2,974,878$ & \\
\hline Finland & 220,025 & 698,657 & 508,749 & 326,213 & 705,536 & $1,753,645$ & \\
\hline Germany & $8,446,743$ & $13,662,309$ & $31,582,732$ & $4,890,089$ & $48,241,129$ & $58,581,872$ & \\
\hline Ireland & 384,705 & 142,705 & 566,270 & 710,783 & $1,058,174$ & $1,804,463$ & \multirow{7}{*}{$\begin{array}{r}\text { Table I. } \\
\text { Nights spent by } \\
\text { non-residents in } \\
\text { hotel establishments } \\
\text { in European Union } \\
\text { Member States of } \\
\text { Southern Europe }\end{array}$} \\
\hline The Netherlands & $3,939,008$ & $2,155,287$ & $2,386,458$ & $1,774,589$ & $5,790,052$ & $10,255,342$ & \\
\hline Sweden & 700,281 & $1,714,393$ & $1,195,886$ & 632,189 & $2,605,828$ & $4,242,749$ & \\
\hline United Kingdom & $15,952,079$ & $8,056,040$ & $8,218,725$ & $7,103,867$ & $40,940,371$ & $39,330,711$ & \\
\hline Sub-total & $35,778,396$ & $31,052,685$ & $52,921,698$ & $16,715,449$ & $107,741,492$ & $136,468,228$ & \\
\hline Total & $71,248,252$ & $43,145,016$ & $95,926,334$ & $23,670,123$ & $145,406,062$ & $379,395,787$ & \\
\hline \multicolumn{7}{|c|}{ Sources: Eurostat (2009); ㄷ EU, 1995-2010 } & \\
\hline
\end{tabular}

\section{Findings and discussion}

The Member States of Southern Europe form the leading tourist destination region in the European Union (EU 27) with a market share of 57.7 per cent of the total nights spent by non-residents in hotel and similar establishments, between 1999 and 2007. However, during this period, they lost market share for the remaining EU countries, namely the new Member Sates (ten in 2004, plus two in 2007), having decreased from 59.5 per cent (1999-2001) to 56.4 per cent (2005-2007).

Spain is the top destination (37.6 per cent of the total nights spent by non-residents, between 1999 and 2007), followed by Italy (26.2 per cent), France (18.9 per cent), Greece (11.0 per cent) and Portugal (6.3 per cent). In the most recent three-year period 
WHATT

2,4

370
(2005-2007), the ratio of nights spent by non-residents per (local) inhabitant, a measure of tourism intensity, was 2.04. Greece (3.77), Spain (3.27) and Portugal (2.28) were above the average and Italy (1.70) and France (1.14) were below the average.

During the period under analysis, Spain (72.7 per cent) and Portugal (67.9 per cent) are the most dependent on the tourist flows from the referred European Union Member States of Central and Northern Europe (Austria, Belgium, Denmark, Finland, Germany, The Netherlands, Ireland, Sweden and the UK), followed by Greece (65.3 per cent), Italy (52.2 per cent) and France (48.6 per cent).

Between 1999 and 2007, the group of generating countries contributed with 61.7 per cent of the total nights spent by non-residents registered in the European Union Member States of Southern Europe (France, Greece, Italy, Portugal and Spain). In spite of the decrease in the relative importance of the generating countries during the last nine years (64.4 per cent between 1999 and 2001; 61.8 per cent between 2002 and 2004 and 58.9 per cent between 2005 and 2007) they still represent the main markets for those destinations.

Germany and the UK are the leading origins, respectively, representing 40.5 and 35.5 per cent of the market, followed by The Netherlands (6.7 per cent) and Belgium (6.5 per cent). The remaining five countries (Austria, Sweden, Ireland, Denmark and Finland) do not surpass 10.8 per cent of the nights spent by non-residents in hotel establishments. The global recovery in the most recent three-year period (2005-2007) was not enough to eliminate the losses of the previous three-year period (2002-2004). Germany is at the top, with a decrease of 15 per cent.

In the most recent three-year period (2005-2007), the generating countries produced 1.16 nights spent per capita in hotel establishments at the European Union Member States of Southern Europe. Belgium (1.43), the UK (1.40) and Ireland (1.33) are the heavy users, Germany (1.10), Austria (0.99) and The Netherlands (0.98) the medium-users and, finally, Denmark (0.68), Sweden (0.68) and Finland (0.52) are the light-users.

Spain is more competitive (SD $>0$ ) in the UK and in Germany, the two main generating countries (Table II). At the remaining countries Spain's market share is below its average market share $(\mathrm{SD}<0)$. Spain shows stronger gains in market share in the most recent three-year period (2005-2007) than the losses occurred in the previous period (2002-2004). The SV, compute as a difference between annual growth rates, is positive in Denmark, Ireland and the UK for both periods (Table III).

Italy presents the best relative performances $(\mathrm{SD}>0)$ in the geographically closest markets (Austria and Germany). Despite the reduction of its main market (Germany), Italy is the only destination with global gains in market share for both periods.

Like Italy, France presents best relative performances $(\mathrm{SD}>0)$ in the geographically closest markets (Belgium, The Netherlands and the UK). Contrary to Spain, France shows deeper losses in market share in the most recent three-year period (2005-2007) than the gains occurred in the previous period (2002-2004). The SV is negative, for both periods, in Sweden and Finland, the most distant markets.

Greece, the most peripheral destination, is more competitive $(\mathrm{SD}>0)$ in the Nordic countries (Finland, Sweden and Denmark). Contrary to Italy, it is the only destination with global losses in market share for both periods. The SV is negative, for both periods, in six out of nine generating countries.

Portugal is less competitive $(\mathrm{SD}<0$ ) in Austria, Belgium and Germany, the only generating countries with border land frontiers with other destinations 


\begin{tabular}{|c|c|c|c|c|c|c|}
\hline Country of residence & France & Greece & Italy & Portugal & Spain & \multirow{2}{*}{$\begin{array}{l}\text { competitive } \\
\text { destination } \\
\text { analysis }\end{array}$} \\
\hline \multicolumn{6}{|l|}{2006} & \\
\hline Austria & -66.7 & 75.5 & 155.8 & -48.0 & -68.0 & \multirow{5}{*}{371} \\
\hline Belgium & 139.7 & -7.3 & -18.2 & -47.1 & -25.8 & \\
\hline Denmark & -17.8 & 74.7 & 11.1 & 53.3 & -26.0 & \\
\hline Finland & -50.9 & 138.3 & 6.3 & 99.9 & -35.5 & \\
\hline Germany & -46.9 & -6.8 & 33.7 & -39.0 & 5.4 & \\
\hline The Netherlands & 51.8 & 39.8 & -22.6 & 57.9 & -23.3 & \\
\hline Ireland & -19.9 & -59.1 & 5.4 & 148.2 & -5.3 & \\
\hline UK & 28.6 & -18.1 & -44.8 & 25.9 & 13.9 & \\
\hline Sweden & -37.2 & 102.1 & 0.4 & 29.7 & -17.4 & \\
\hline \multicolumn{7}{|l|}{2003} \\
\hline Austria & -66.5 & 80.9 & 165.8 & -56.9 & -72.8 & \\
\hline Belgium & 110.5 & -13.9 & -22.2 & -50.9 & -16.8 & \\
\hline Denmark & 5.0 & 100.3 & -0.3 & 33.7 & -33.4 & \\
\hline Finland & -54.7 & 144.8 & -9.0 & 132.8 & -35.0 & \\
\hline Germany & -44.9 & -0.8 & 44.8 & -36.6 & -0.5 & \\
\hline The Netherlands & 63.0 & 7.6 & -28.5 & 55.8 & -19.2 & \\
\hline Ireland & -31.3 & -52.7 & -14.0 & 235.1 & -5.7 & \\
\hline UK & 27.5 & -18.3 & -51.3 & 21.9 & 17.5 & \\
\hline Sweden & -37.7 & 106.9 & -11.3 & 52.2 & -17.0 & \\
\hline \multicolumn{7}{|l|}{2000} \\
\hline Austria & -66.0 & 82.8 & 161.6 & -53.0 & -73.1 & \\
\hline Belgium & 115.9 & -25.0 & -26.4 & -49.5 & -10.6 & \\
\hline Denmark & 12.9 & 98.3 & -4.0 & 58.5 & -39.7 & Table II. \\
\hline Finland & -38.9 & 123.4 & -4.5 & 93.8 & -35.0 & SD of nights spent by \\
\hline Germany & -46.0 & 0.6 & 36.4 & -33.1 & 2.4 & non-residents in hotel \\
\hline The Netherlands & 67.6 & 5.6 & -31.4 & 61.6 & -18.2 & establishments \\
\hline Ireland & -8.3 & -60.8 & -8.7 & 262.8 & -16.2 & in European Union \\
\hline UK & 35.6 & -21.1 & -52.8 & 29.3 & 15.6 & Member States of \\
\hline Sweden & -30.2 & 96.9 & -19.4 & 34.9 & -13.8 & Southern Europe \\
\hline
\end{tabular}

(Austria with Italy; and Belgium and Germany with France). The losses in market share in the most recent three-year period (2005-2007) do not eliminate the gains occurred in the previous period (2002-2004). Portugal faced the deepest losses in market share from the country where it has been more competitive (Ireland).

Figures 2 and 3 show the MSA results for a destination (e.g. Portugal) and for an origin (e.g. the UK).

\section{Implications and conclusion}

Lessons for practice

The results obtained lead to the rejection of $H 1$ (the relative tourist competitiveness of Spain, France, Greece, Italy and Portugal has not changed) and provide support for H2 (the countries present distinct levels of tourist competitiveness for the various countries of origin). Between the first three-year period (1999-2001) and the most recent one (2005-2007), the total nights spent by non-residents at Member States of Southern Europe increased by 4.5 per cent but from other Member States of Central and Northern Europe decreased by 4.3 per cent. During that period, Italy was the only country showing no reduction $(+0.6$ per cent), and Spain $(-1.2$ per cent) and Portugal 


\section{WHATT \\ 2,4}

\begin{tabular}{|c|c|c|c|c|c|}
\hline Country of residence & France & Greece & Italy & Portugal & Spain \\
\hline \multicolumn{6}{|l|}{$2006-2003$} \\
\hline Austria & -3.6 & -2.9 & -0.5 & 6.2 & 7.0 \\
\hline Belgium & 0.9 & 0.6 & 2.5 & 2.3 & -2.5 \\
\hline Denmark & -11.9 & -6.8 & 4.8 & 4.8 & 5.4 \\
\hline Finland & -0.8 & -2.9 & 6.5 & -5.5 & 1.1 \\
\hline Germany & -4.5 & -3.9 & -1.9 & -1.5 & 3.3 \\
\hline The Netherlands & -5.7 & 7.2 & 3.5 & 0.2 & -0.5 \\
\hline Ireland & 1.9 & -7.1 & 8.5 & -10.7 & 1.6 \\
\hline UK & -3.1 & -1.9 & 4.9 & 0.7 & 0.2 \\
\hline Sweden & -3.1 & -2.7 & 5.1 & -5.5 & 1.1 \\
\hline Total & -3.4 & -1.9 & 0.8 & -0.3 & 1.3 \\
\hline \multicolumn{6}{|l|}{$2003-2000$} \\
\hline Austria & 1.9 & -3.7 & 1.4 & -1.9 & -0.1 \\
\hline Belgium & 1.6 & 1.0 & 2.7 & -0.1 & -2.7 \\
\hline Denmark & 0.0 & -3.0 & 2.1 & -4.4 & 2.7 \\
\hline Finland & -7.0 & -0.5 & -0.7 & 7.0 & -0.5 \\
\hline Germany & 3.0 & -3.7 & 2.7 & -0.8 & -1.3 \\
\hline The Netherlands & 1.5 & -2.9 & 2.2 & -0.3 & -0.8 \\
\hline Ireland & -8.0 & 3.1 & -1.2 & -2.0 & 4.1 \\
\hline UK & 0.4 & -2.5 & 2.0 & -1.1 & 0.1 \\
\hline Sweden & -1.3 & -1.8 & 4.0 & 4.8 & -1.6 \\
\hline Total & 2.4 & -3.4 & 0.9 & 0.9 & -0.4 \\
\hline
\end{tabular}

Table III.

SV of nights spent by non-residents in hotel establishments in European Union Member States of Southern Europe

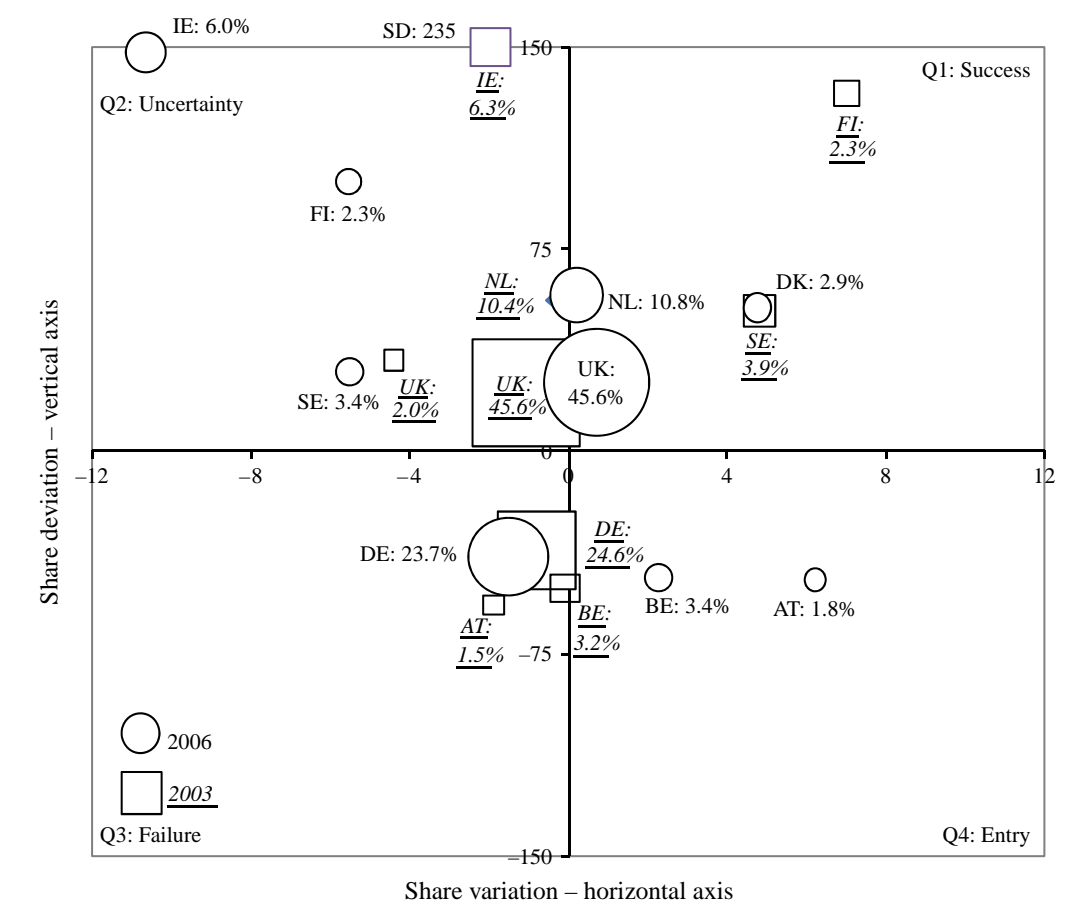

Figure 2.

MSA: destination Portugal 


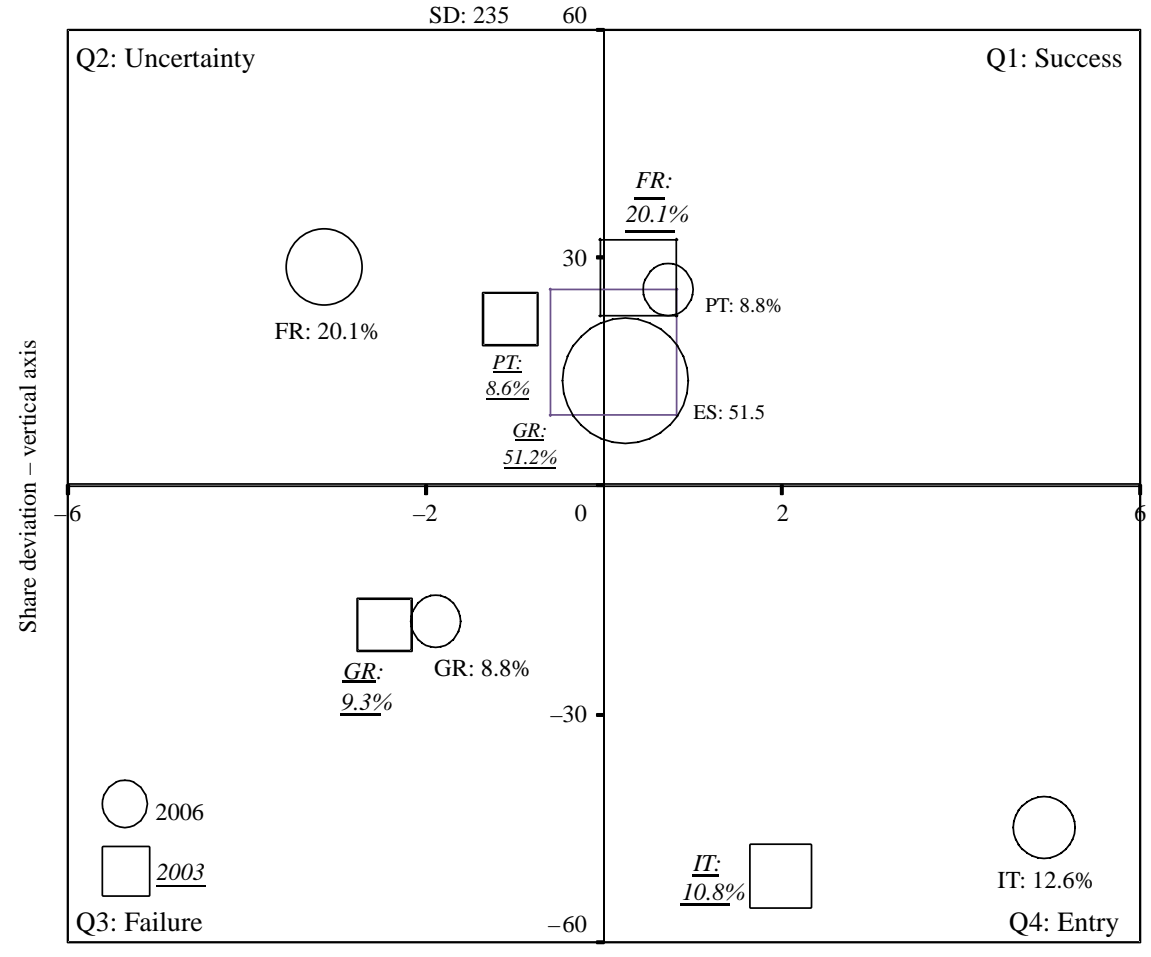

Share variation - horizontal axis
Competitive destination analysis

373

Figure 3. MSA: origin UK

$(-2.4$ per cent) present a decrease below the global value $(-4.3$ per cent). Greece ( -18.8 per cent) and France ( -7.0 per cent) are both on the loosing side.

Southern European countries are still the main tourist destination region in the EU but they should be concerned with the market share decrease, which means that they are becoming less competitive, at least from the hotel industry perspective. However, it is reasonable to admit that other accommodation options, such as the second homes, may have had a different evolution in the same period.

Nevertheless, as a mature destination, Southern European countries need to increase the product diversification and to find out new markets, not only in Europe. They also need to monitor the level of consumption of their main international markets, which includes the Member States of Central and Northern Europe.

The geographic coordinates of both destinations and origins, seem to have a strong influence, but not equal, in the performance. The diversity of the results obtained allows us to foresee that they are not the fruit of random factors and that they stem from different levels and dynamics of competitiveness. In other words, there are no pre-determined results and the management of internal factors (competitiveness) should play a crucial role in the success of the destinations.

The MSA proves itself as an adequate tool for the study of tourist competitiveness and, therefore, a valuable instrument for supporting the targeting strategies of National Tourism Organisations. The main advantage of the MSA is its simplicity and 
WHATT

2,4

\section{4}

\section{References}

Bonn, M. and Brand, R. (1995), "Identifying market potential: the application of brand development indexing to pleasure travel", Journal of Travel Research, Vol. 34 No. 2, pp. 31-5.

Buhalis, D. (2000), "Marketing the competitive destination of the future", Tourism Management, Vol. 21 No. 1, pp. 97-116.

Calantone, R. and Mazanec, J. (1991), "Marketing management and tourism”, Annals of Tourism Research, Vol. 18 No. 1, pp. 101-19.

Cracolici, M.F. and Njikamp, P. (2008), "The attractiveness and competitiveness of tourist destinations: a study of Southern Italian Regions", Tourism Management, Vol. 30 No. 3, pp. 336-44.

Crouch, G.I. and Ritchie, J.R.B. (1999), "Tourism, competitiveness, and societal prosperity", Journal of Business Research, Vol. 44 No. 3, pp. 137-52.

Durbarry, R. and Sinclair, M.T. (2003), "Market shares analysis: the case of French tourism demand", Annals of Tourism Research, Vol. 30 No. 4, pp. 927-41.

Dwyer, L. and Kim, C. (2003), "Destination competitiveness: determinants and indicators", Current Issues in Tourism, Vol. 6 No. 5, pp. 369-413.

Enright, M. and Newton, J. (2004), "Tourism destination competitiveness: a quantitative approach”, Tourism Management, Vol. 25 No. 6, pp. 777-88.

Eurostat (2009), "Statistics by theme", available at: http://epp.eurostat.ec.europa.eu/portal/page/ portal/tourism/data/database (accessed 20 April 2009).

Eusebio, R., Andreu, J.B. and Belbeze, M.P.L. (2006), "Measures of marketing performance: a comparative study from Spain", International Journal of Contemporary Hospitality Management, Vol. 18 No. 2, pp. 145-55.

Faulkner, B. (1997), "A model for the evaluation of national tourism destination marketing programs”, Journal of Travel Research, Vol. 35 No. 3, pp. 23-32.

Feurer, R. and Chaharbaghi, K. (1994), "Defining competitiveness: a holistic approach", Management Decision, Vol. 32 No. 2, pp. 49-58.

Gearing, C., Swart, W. and Var, T. (1974), "Establishing a measure of touristic attractiveness", Journal of Travel Research, Vol. 12 No. 4, pp. 1-8.

Gomezelj, D. and Mihalic, T. (2008), "Destination competitiveness-applying different models, the case of Slovenia", Tourism Management, Vol. 29 No. 2, pp. 294-307.

Henshall, B. and Roberts, R. (1985), “Comparative assessment of tourist generating markets for New Zealand”, Annals of Tourism Research, Vol. 12 No. 2, pp. 219-38.

Kozak, M. and Rimmington, M. (1999), "Measuring tourist destination competitiveness: conceptual considerations and empirical findings", International Journal of Hospitality Management, Vol. 18 No. 3, pp. 273-83.

Lee, G., Morrison, A. and O'Leary, J.T. (2006), "The economic value portfolio matrix: a target selection tool for destination marketing organizations", Tourism Management, Vol. 27 No. 4, pp. 576-88. 
Loker, L. and Perdue, R. (1992), "A benefit-based segmentation of a nonresident summer travel market”, Journal of Travel Research, Vol. 31 No. 1, pp. 30-5.

Mazanec, J. (1986a), “Allocating an advertising budget to international travel markets”, Annals of Tourism Research, Vol. 13 No. 4, pp. 609-34.

Mazanec, J. (1986b), "How to evaluate a travel market: econometric modeling vs. multi-attribute decision making with management estimates", Centre des Hautes Études Touristiques Série C, No. 48, Mai, Aix-en-Provence.

McKercher, B. (1995), "The destination-market matrix: a tourism market portfolio analysis model”, Journal of Travel and Tourism Marketing, Vol. 4 No. 2, pp. 23-40.

Mazanec, J. (1995), “Análise da Posição Estratégica de Cidades Turísticas: Um Estudo para Lisboa", Revista Portuguesa de Gestão, Nos 2/3, pp. 83-94.

Mihalic, T. (2000), "Environmental management of a tourist destination: a factor of tourism competitiveness", Tourism Management, Vol. 21 No. 1, pp. 65-78.

Porter, M. (1990), The Competitive Advantage of Nations, Macmillan, London.

Rita, P. (1992), "An expert support system for promotional budget allocation in national tourist offices", Service Industries Management Research Unit, working paper series, Cardiff Business School, Cardiff.

Ritchie, J.R.B. and Crouch, G.I. (1993), "Competitiveness in international tourism- a framework for understanding and analysis", unpublished paper, World Tourism Education and Research Centre, The University of Calgary, Alberta.

Ruhanen, L. (2007), "Destination competitiveness", in Matias, A., Nijkamp, P. and Neto, P. (Eds), Advances in Modern Tourism Research, Physika, Heidelberg, pp. 133-52.

Smeral, E. and Witt, S. (2002), "Destination country portfolio analysis: the evaluation of national tourism destination marketing programs revisited", Journal of Travel Research, Vol. 40 No. 3, pp. 287-94.

Wynegar, D. (1994), "Estimating the potential of international markets", in Ritchie, J. and Goeldner, C. (Eds), Travel, Tourism and Hospitality Research, Wiley, New York, NY, pp. 597-606.

\section{Corresponding author}

Paulo Águas can be contacted at: paguas@ualg.pt
Competitive destination analysis

To purchase reprints of this article please e-mail: reprints@emeraldinsight.com Or visit our web site for further details: www.emeraldinsight.com/reprints 